\title{
Evaluation of bioregulators use under various keeping conditions of barren cows
}

\author{
Albina Aminova ${ }^{1}$, Munir Sabitov ${ }^{1}$, Albina Farkhutdinova $^{1}$, Idris Yumaguzin $^{1}$, and Tatiana \\ Sedykh ${ }^{1,2, *}$ \\ ${ }^{1}$ Bashkir Research Institute of Agriculture - a separate structural unit of the Ufa Federal Research \\ Center of the Russian Academy of Sciences, Ufa, Russia \\ ${ }^{2}$ Federal State Budgetary Educational Institution of Higher Education Bashkir State Pedagogical \\ University named after M. Akmulla, Ufa, Russia
}

\begin{abstract}
The experiments were carried out in herds with repeatedly barren animals after insemination to study the reproductive ability of cows under different keeping conditions. As a result, the efficiency of insemination of double-barren cows was higher in synchronised heat with gonadotropin and prostaglandin. It ranged from 48 to $70 \%$, while the effect of exposure to drugs was higher in all cows with loose housing. After synchronisation of heat in cows with loose housing, with the introduction of surfagon before insemination, the fertilisation rate was $70 \%$, ovulin $63.3 \%$, with control $46.6 \%$, with tethered housing - 60; 63.3 and $33.3 \%$, respectively. However, all groups must identify cows in the heat for at least 72 hours. Otherwise, it is predicted that the measures' effectiveness will decrease by $30 \%$ or more.
\end{abstract}

\section{Introduction}

An increase in the productivity of dairy cattle breeding depends on its modernisation, the use of resource-saving technologies aimed at the intensive use of animals at economically and zootechnically reasonable labour, material and energy costs. Therefore, the correct choice of technology for keeping animals determines milk production volume and quality [1]. Many aspects influence the productivity of dairy cows, for example, breed, heredity, maintenance, physiological state of animals, nutritional status, feeding, age, milking technology $[2 ; 3]$.

The world practice of livestock breeding shows that the level of feeding and the quality of feed (by 50-60\%) affects the milk productivity of cows; the rest falls on selection work, herd reproduction, housing conditions and milking technology [4].

The most common cause of reproduction disorders in cows is the change in the generative and hormonal functions of the ovaries. Functional ovarian dysfunction (hypofunction of the ovaries, persistent corpus luteum, follicular and luteal cysts) is clinically manifested by anaphrodisia (absence of sex cycles), inadequate sex cycles and nymphomania.

\footnotetext{
*Corresponding author: sci_secr_bniish@bk.ru
} 
In dairy cattle breeding, a tethered and loose method of keeping cows is used. In our country, the tethered way of keeping is traditional due to the rational distribution of feed and individual service by the milkmaid of 50 cows. However, the most cost-effective way of keeping cows on dairy farms is loose since it is closer to animal life's biological conditions $[5 ; 6 ; 7]$. With this method of keeping, an increase in milk productivity is observed and a decrease in the insemination index and a reduction in the duration of the service period $[8,9]$.

In the practice of cattle breeding, a big problem is presented by animals that did not become pregnant due to latent functional disorders of the reproductive function, including those with a service period of more than 150 days after calving. It should include $10 \%$ of cows that did not become pregnant in total after three inseminations. Such animals fall into the category of "problem cows". According to various sources, the number of "problem cows" in herds can vary from 20 to $80 \%$ [10]. Particular interventions are recommended, including introducing modern bioregulators to achieve the fertility indicators regulated by the norms $[11 ; 12]$.

It is necessary to consider the content of vitamins when rationing the diet to determine the genetically determined resources of animal productivity. They are vital for the normal functioning of the cow's body, ensuring high productivity and reproductive function. Lack of at least one vitamin in the diet leads to metabolic disorders and a decrease in the productivity of animals.

The use of drugs of the prostaglandin series to induce sexual heat in the maximum number of treated animals to subsequently receive round calving does not always lead to the desired results [13]. Perhaps this circumstance is because physiological transformations in the body of animals after exposure to drugs have some discrepancies due to different conditions of detention [14]. Therefore, the elucidation of physiological changes after injections of domestically produced drugs with various keeping animals is of great importance and relevance.

The research aims to study the reproductive function of cows under various conditions of keeping.

\section{Materials and methods}

The experiments were carried out in 2018-2020. Scientific research was carried out at the farm of the "Plemzavod-Alga" in Krasnokamsky District of the Republic of Bashkortostan with a tethered and loose method of keeping black-and-white cows.

The experiments were carried out in herds with cows who repeatedly remained barren after insemination (at the age of three to five years, with a milk yield per lactation of 6500 $\mathrm{kg}$ ). One control and two experimental groups of animals were formed with unsatisfactory fertility indicators, while clinical signs of abnormalities in the reproductive system were not found.

Rectal examinations of cows were carried out to determine the nature of the ovarian activity.

Complete feed for cows is made from the concentrated feed of our products to include missing vitamin and mineral part. The ration of dairy cows consisted of clover hay, alfalfa haylage, corn silage, concentrates, beet molasses.

The vitamin and amino acid preparation Vitam, tested in our work, contains a balanced amount of amino acids, vitamins, trace elements and glucose.

The use of preparations, insemination of cows was carried out according to the methods and instructions and instructions attached to the official forms of preparations. The conditions of feeding and keeping were following zootechnical standards. The digital 
material is grouped according to the studied indicator and biometrically processed using MS Excel.

\section{Results and discussion}

The first experimental group of cows was synchronised with the luteolytic preparation estrophan with a recommended intramuscular dose of $2 \mathrm{ml}(500 \mu \mathrm{g}$ of the active substance cloprostenol). After examination, all animals of the second experimental group were injected with gonadotropin of the serum of pregnant mares (PMSG) 1500 IU, after 48 hours, the drug estrophan.

All groups were divided into subgroups, where the distinction was different ways of keeping cows - loose and tethered.

The test results showed that the fertilisation index values after frontal insemination and the heat were detected the highest in the second experimental group and ranged from 48 to $70 \%$ (table 1). At the same time, the effect of exposure to drugs was higher in all cows with loose housing.

In this experiment, a tendency to increase the result of exposure to hormones with an increase in the period after calving was noted, directly related to the activation of the ovarian follicular system and the normalisation of the hypothalamic-pituitary-ovarian connection. The growth rate of follicles also increased during stimulation long after calving.

Table 1. The efficiency of insemination of double-barren cows in synchronised heat.

\begin{tabular}{|c|c|c|c|c|c|c|c|c|c|}
\hline \multirow{5}{*}{$\begin{array}{c}\text { Subgrou } \\
\text { p }\end{array}$} & \multirow{2}{*}{\multicolumn{3}{|c|}{$\frac{1 \text { experimental group }}{\text { estrophan }}$}} & \multirow{2}{*}{\multicolumn{3}{|c|}{$\begin{array}{l}2 \text { experimental group } \\
\text { PMSG Estrophan }\end{array}$}} & & \multirow{2}{*}{\multicolumn{2}{|c|}{ Control group }} \\
\hline & & & & & & & & & \\
\hline & \multicolumn{9}{|c|}{ Cows inseminated } \\
\hline & $\begin{array}{c}\text { tota } \\
1\end{array}$ & $\begin{array}{c}\text { productiv } \\
\mathrm{e}\end{array}$ & $\begin{array}{c}\text { fertilit } \\
y\end{array}$ & $\begin{array}{c}\text { tote } \\
1\end{array}$ & $\begin{array}{c}\text { productiv } \\
\mathrm{e}\end{array}$ & $\begin{array}{c}\text { fertilit } \\
y\end{array}$ & $\begin{array}{c}\text { tota } \\
1\end{array}$ & $\underset{\mathrm{e}}{\text { producti }}$ & $\begin{array}{c}\text { fertilit } \\
y\end{array}$ \\
\hline & $\mathrm{n}$ & $\mathrm{n}$ & $\%$ & $\mathrm{n}$ & $\mathrm{n}$ & $\%$ & $\mathrm{n}$ & $\mathrm{n}$ & $\%$ \\
\hline \multicolumn{10}{|c|}{ Frontal insemination after 48 hours } \\
\hline I* & 20 & 9 & 45,0 & 25 & 12 & 48,0 & 10 & - & - \\
\hline II $* *$ & 25 & 13 & 52,0 & 25 & 14 & 56,0 & 10 & 3 & 30,0 \\
\hline \multicolumn{10}{|c|}{ Insemination as heat is detected } \\
\hline$\overline{I *}$ & 25 & 14 & 56,0 & 18 & 12 & 66,7 & 10 & 1 & 10,0 \\
\hline II $*$ & 20 & 12 & 60 & 30 & 21 & 70 & 10 & 2 & 20,0 \\
\hline
\end{tabular}

* Tethered way of keeping

** Loose way of keeping

In the next experiment, the effectiveness of the introduction of surfagon and ovulin was determined before insemination of barren cows in spontaneous and synchronised heat. Before the experiment, the uterus was sanitised with monclavite-1 in all groups. The cows were kept loose and tied.

Table 2. The effectiveness of the introduction of surfagon and ovulin before insemination of barren cows in spontaneous and synchronised heat.

\begin{tabular}{|c|c|c|c|}
\hline \multirow{2}{*}{$\begin{array}{c}\text { Subgrou } \\
\text { p }\end{array}$} & 1 experimental group & 2 experimental group & \multirow{2}{*}{ Control group } \\
\cline { 2 - 3 } & Surfagon & Ovulin & \\
\hline
\end{tabular}




\begin{tabular}{|c|c|c|c|c|c|c|c|c|c|}
\hline & \multicolumn{9}{|c|}{ Cows inseminated } \\
\hline & $\begin{array}{c}\text { tota } \\
1\end{array}$ & $\begin{array}{c}\text { productiv } \\
\mathrm{e}\end{array}$ & $\begin{array}{c}\text { fertilit } \\
\mathrm{y}\end{array}$ & $\begin{array}{c}\text { tota } \\
1\end{array}$ & $\begin{array}{c}\text { productiv } \\
\mathrm{e}\end{array}$ & $\begin{array}{c}\text { fertilit } \\
\mathrm{y}\end{array}$ & $\begin{array}{c}\text { tota } \\
1\end{array}$ & $\begin{array}{c}\text { productiv } \\
\mathrm{e}\end{array}$ & $\begin{array}{c}\text { fertilit } \\
\mathrm{y}\end{array}$ \\
\hline & $\mathrm{n}$ & $\mathrm{n}$ & $\%$ & $\mathrm{n}$ & $\mathrm{n}$ & $\%$ & $\mathrm{n}$ & $\mathrm{n}$ & $\%$ \\
\hline \multicolumn{10}{|c|}{ Loose way of keeping } \\
\hline $\mathrm{I} *$ & 30 & 6 & 20.0 & 30 & 6 & 20.0 & 30 & 2 & 6.7 \\
\hline $\mathrm{II} * *$ & 30 & 21 & 70.0 & 30 & 19 & 63.3 & 30 & - & 46.6 \\
\hline \multicolumn{10}{|c|}{ Tethered way of keeping } \\
\hline $\mathrm{I} *$ & 30 & 3 & 10.0 & 30 & 4 & 13.3 & 30 & 1 & 3.0 \\
\hline II* & 30 & 18 & 60.0 & 30 & 19 & 63.3 & 30 & 10 & 33.3 \\
\hline
\end{tabular}

* Spontaneous heat

** Synchronized heat (synchronization scheme - PMSG $+\mathrm{PGF}_{2} \alpha$ )

The heat start after injection of prostaglandin does not affect the fertility rates of the experimental groups, which are approximately equal (Table 2). After synchronising heat in cows of experimental groups with loose housing, with the introduction of surfagon before insemination, the fertilisation rate was $70 \%$, ovulin - $63.3 \%$, with control $46.6 \%$, with tethered housing - 60; 63.3 and $33.3 \%$, respectively. However, all groups must identify cows in the heat for at least 72 hours. Otherwise, it is predicted that the measures' effectiveness will decrease by $30 \%$ or more.

Table 3. Fertility of cows, depending on the timing of the heat start after injection of prostaglandin with different methods of keeping*.

\begin{tabular}{|c|c|c|c|c|c|c|}
\hline \multirow{2}{*}{$\begin{array}{l}\text { Time } \\
\text { of the } \\
\text { heat } \\
\text { start }\end{array}$} & \multicolumn{3}{|c|}{ Loose way of keeping } & \multicolumn{3}{|c|}{ Tethered way of keeping } \\
\hline & $\begin{array}{c}\text { Number of } \\
\text { inseminated } \\
\text { cows, } n\end{array}$ & $\begin{array}{c}\text { Number } \\
\text { of } \\
\text { pregnant } \\
\text { cows, } n\end{array}$ & $\begin{array}{c}\text { Fertility, } \\
\%\end{array}$ & $\begin{array}{c}\text { Number of } \\
\text { inseminated } \\
\text { cows, } n\end{array}$ & $\begin{array}{c}\text { Number of } \\
\text { pregnant } \\
\text { cows, n }\end{array}$ & Fertility, \% \\
\hline 12 & - & - & - & - & - & - \\
\hline 24 & 5 & 2 & 40.0 & 6 & 2 & 33.3 \\
\hline 36 & 8 & 3 & 37.5 & 8 & 3 & 37.5 \\
\hline 48 & 53 & 26 & 49.1 & 49 & 24 & 49.0 \\
\hline 60 & 9 & 4 & 44.4 & 8 & 3 & 37.5 \\
\hline 72 & 7 & 3 & 42.9 & 9 & 4 & 44.4 \\
\hline Всего & 82 & 38 & 46.3 & 80 & 36 & 45.0 \\
\hline
\end{tabular}

* 180 heads worked

As a result of Table 3 analysis, it was established that when the cows were injected with the estrophan preparation in the middle of the oestrous cycle, the maximum number of animals without a leash (53 heads) and on a leash (49 heads) showed heat and were inseminated after 48 hours. It is the best time for the maturation of a full-fledged follicle.

Thus, the value of the pregnancy parameter, which is the leading indicator of synchronisation efficiency, was the highest in cows that came into heat 48 hours after hormonal treatment, and with both methods of keeping was about $49 \%$.

In the next cycle of studies, the primary attention is paid to elucidating an effective method for activating the reproductive function of cows by introducing a vitamin 
preparation into the scheme of hormonal treatment of animals. It also determined the effectiveness of the use of drugs ovulin and Vitam to stimulate heat in experimental animals with different methods of keeping (Table 4).

Table 4. Scheme of scientific and production experience with the use of ovulin and vitamin Vitam with different methods of keeping

\begin{tabular}{|l|c|l|}
\hline Group & $\begin{array}{l}\text { Number, } \\
\text { heads }\end{array}$ & Features of drugs use \\
\hline $\begin{array}{l}\text { control (tethered way of } \\
\text { keeping) }\end{array}$ & 10 & essential diet \\
\hline tethered way of keeping & 10 & $\begin{array}{l}\text { essential diet }+ \text { Vitam, } 5 \mathrm{ml} \text { per } 10 \mathrm{~kg} \text { of live } \\
\text { weight (therapeutic dose), ovulin, } 5 \mathrm{ml}\end{array}$ \\
\hline loose way of keeping & 10 & \\
\hline
\end{tabular}

Stimulation of hunting was carried out according to the scheme in cows on tethered and loose methods of keeping - vitamin preparation Vitam - therapeutic dose $(5 \mathrm{ml})$ per $10 \mathrm{~kg}$ of live weight, two times a day for five days, after two days $5 \mathrm{ml}$ of ovulin, respectively, in groups. The cows in the control group received only the essential diet.

The cows identified in the hunt were artificially inseminated.

Table 5. Morphological and biochemical parameters of blood and serum of cows (on average per 1 head).

\begin{tabular}{|l|c|c|c|}
\hline \multirow{2}{*}{ Indicator } & \multicolumn{3}{|c|}{ Group } \\
\cline { 2 - 4 } & \multirow{2}{*}{ control } & \multicolumn{2}{c|}{ experimental } \\
\cline { 2 - 4 } & & $\begin{array}{c}\text { tethered way of } \\
\text { keeping }\end{array}$ & $\begin{array}{c}\text { loose way of } \\
\text { keeping }\end{array}$ \\
\hline Erythrocytes, $\mathrm{mln} / \mu \mathrm{l}$ & $6.0 \pm 0.13$ & $6.1 \pm 0.12$ & $6.3 \pm 0.11$ \\
\hline Leukocytes, thousand / $\mu \mathrm{l}$ & $7.8 \pm 0.14$ & $8.0 \pm 0.16$ & $8.3 \pm 0.16$ \\
\hline Hemoglobin, $\mathrm{g} \%$ & $10.9 \pm 0.21$ & $11.6 \pm 0.23$ & $12.2 \pm 0.18$ \\
\hline Total protein, g $\%$ & $7.8 \pm 0.13$ & $8.1 \pm 0.16$ & $8.2 \pm 0.15$ \\
\hline Nitrogen index & $0.23 \pm 0.04$ & $0.33 \pm 0.02$ & $0.35 \pm 0.03$ \\
\hline Total lipids, $\mathrm{mg} \%$ & $473.5 \pm 20.24$ & $512 \pm 20.62$ & $514 \pm 20.23$ \\
\hline Total calcium, $\mathrm{mg} \%$ & $10.6 \pm 0.93$ & $11.3 \pm 0.87$ & $11.9 \pm 0.79$ \\
\hline Urea, mol / 1 & $5.9 \pm 0.24$ & $5.7 \pm 0.18$ & $5.6 \pm 0.13$ \\
\hline $\begin{array}{l}\text { Inorganic phosphorus, } \\
\mu \mathrm{g} \%\end{array}$ & $4.9 \pm 0.23$ & $5.4 \pm 0.22$ & $5.8 \pm 0.26$ \\
\hline Ketone bodies, $\mathrm{mg} \%$ & $2.2 \pm 0.21$ & $2.0 \pm 0.18$ & $1.9 \pm 0.14$ \\
\hline Sugar (glucose), $\mathrm{mg} \%$ & $55 \pm 0.16$ & $53 \pm 0.19$ & $52 \pm 0.16$ \\
\hline Carotene, $\mathrm{mg} \%$ & $0.4 \pm 0.16$ & $0.6 \pm 0.16$ & $0.7 \pm 0.14$ \\
\hline
\end{tabular}

Analysis of the biochemical and morphological parameters of the blood of experimental animals shows the positive effect of the vitamin-amino acid complex Vitam on cows' metabolism.

In the blood of cows, there is an increase in the content of erythrocytes and leukocytes and total protein, carotene, and a decrease in the level of urea, ketone bodies, and glucose. Thus, the level of erythrocytes of cows in the experimental groups increased on average by 1.67$5.0 \%$, leukocytes - by $2.56-6.41 \%$, total protein - by $3.85-5.13 \%$. At the same time, in animals of the experimental groups, compared with control cows, the content of urea decreased by $3.4-5.1 \%$, sugar - by $3.64-5.45 \%$, ketone bodies - by $9.1-13.6 \%$ ( Table 5).

Table 6. The effectiveness of the use of drugs ovulin and Vitam on barren cows with different methods of keeping.

\begin{tabular}{|c|c|c|c|}
\hline \multirow{2}{*}{ Index } & \multirow{2}{*}{ control } & \multicolumn{2}{|c|}{ Group } \\
\cline { 3 - 4 } & & tethered way of & loose way of \\
\hline
\end{tabular}




\begin{tabular}{|c|c|c|c|}
\hline & & keeping & keeping \\
\hline Total number of cows & 10 & 10 & 10 \\
\hline $\begin{array}{c}\text { Pregnant after first } \\
\text { insemination }\end{array}$ & 5 & 7 & 8 \\
\hline $\begin{array}{c}\text { Pregnant after two } \\
\text { inseminations }\end{array}$ & 8 & 10 & 10 \\
\hline Service-period & $137 \pm 0.03$ & $122 \pm 0.02$ & $120 \pm 0.01$ \\
\hline Insemination index & 2.5 & 2.4 & 2.4 \\
\hline
\end{tabular}

It was found that five cows of the control group became pregnant after the first insemination, i.e. efficiency $(50 \%)$. In cows with a tethered method of keeping, pregnancy was $70 \%$, in the loose way of keeping - $80 \%$ (table 6 ).

When using the gonadotropic preparation ovulin, the service period of cows on the tethered housing was 122 days, in animals on the loose housing with ovulin stimulation - 120 days, i.e. compared with cows in the control group, less, respectively, by 15 and 17 days.

Thus, the vitamin-amino acid complex Vitam stimulates the process of hematopoiesis and enhances the body's nonspecific resistance, has a beneficial effect on metabolic processes, contributes to the effective consumption of feed, and increases the productivity of animals, increasing milk yield to $5.5 \%$.

After applying the vitamin and amino acid preparation Vitam during hunting synchronisation in cows, the service period was reduced to 17 days.

\section{Conclusion}

As a result, the efficiency of insemination of double-barren cows was higher in synchronised heat with gonadotropin and prostaglandin. It ranged from 48 to $70 \%$, while the effect of exposure to drugs was higher in all cows with loose housing. After synchronisation of heat in cows with loose housing, with the introduction of surfagon before insemination, the fertilisation rate was $70 \%$, ovulin $-63.3 \%$, with control $46.6 \%$, with tethered housing - 60; 63.3 and $33.3 \%$, respectively. However, all groups must identify cows in the heat for at least 72 hours. Otherwise, it is predicted that the measures' effectiveness will decrease by $30 \%$ or more.

The value of the fertility rate was the highest in cows that showed heat 48 hours after complex treatment, and with both methods of keeping, it was about $49 \%$.

\section{References}

1. M. Gorbachev, Vestnik MSAU, 7, 95-97 (2009) (In Russ.)

2. S. Karamaev, E. Kitaev, N. Soboleva, Journal of Dairy and Beef Cattle Farming, 3, 36 (2015) (In Russ.)

3. E. Shatskikh, I. Barmina. J. Zootechniya, 11, 3-8 (2016), (In Russ.)

4. I. Donnik, I. Shkuratova, Veterinary medicine of Kuban, 2, 12-13 (2011), (In Russ.)

5. V. Netecha, T. Agalakova, Agricultural Science Euro-North-East, 9, $81-84$ (2007), (In Russ.)

6. M. Kosyreva, H. Valitov, N. Soboleva, S. Karamaev, L. Gladilkina, Vestnik OSAU, 3, 15-1, 149-151 (2007), (In Russ.)

7. S. Popescu, C. Borda, E. Duigan, M. Niculae, R. Stefan, C.D. Sandru, Italian Journal of Animal Science, 13(1), 2940 (2014)

8. O. Mityashova, A. Oborin, A. Chomaev, Animal Husbandry of Russia, 9, 45-46 (2008) (In Russ.) 
9. E. Smirnova, A. Nezhdanov, M. Retsky, E. Bratchenko, N. Papin, A. Stepanov, V. Shushlebin, G. Chusova. Agricultural Biology, 49, 2, 67-71 (2014) (In Russ.)

10. A. Aminova, I. Yumaguzin, N. Fenchenko, N. Khairullina, D. Shamsutdinov, Journal of Dairy and Beef Cattle Farming, 6, 29-31 (2019) (In Russ.) DOI: 10.33943/MMS. 2019. 6. 39674

11. I. Mikhailenko, Agricultural Biology, 49, 2, $50-58$ (2014) (In Russ.)

12. A. Pankratova, A. Aminova, S. Kozyrev, M. Al-Azawi Nagham. Plant Archives, 19, 24-30 (2019)

13. Fu Changqi, Mao Wei, Gao Ruifeng, et al. Animal Reproduction Science, 213, $106276(2020)$

14. T. Kulakova, L. Efimova, O. Ivanova, Bulletin of ASAU, 8 (154), 127-132 (2017). (In Russ.) 